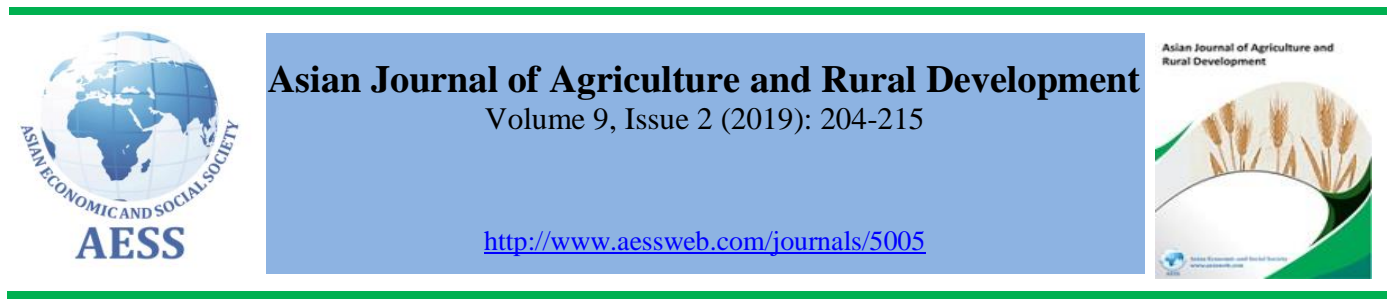

\title{
STABILITY AND ADAPTABILITY GENOTYPE OF HYBRID RICE IN THE WEST JAVA PROVINCE OF INDONESIA
}

Lia Amalia a, a Department of Agrotechnology, Faculty of Agriculture, Winaya Mukti

Ai Komariah a, University, Indonesia

Ilma Hilmayanti ${ }^{\text {b }}$

${ }^{\mathrm{b}}$ BPSBTPH of West Java Province, Indonesia

\吕8264@yahoo.com (Corresponding author)

\section{ARTICLE HISTORY: \\ Received: 08-May-2019 \\ Accepted: $12-$ Sep-2019 \\ Online Available: 24-Sep- 2019}

\section{Keywords: \\ Adaptability, \\ Genotype, \\ Hybrid rice, \\ Stability}

\begin{abstract}
Experiments to study the stability and adaptability genotype of hybrid rice were conducted in two locations in West Java: 1. the Jelekong Village Baleendah Bandung region, 2. the Arjasari Village Leuwisari Tasikmalaya region. The altitude of the Baleendah Bandung region is 650 and that of the Leuwisari Tasikmalaya region is 450 meters above sea level. The experiments were arranged in a randomized block design and used with 9 genotypes and 3 replications. The 9 genotypes of hybrid rice are SW-907, SW804, SW-902, US-915, SW-82, SW-923, Intani-2, SL 8 SHS, and SHS $04 \mathrm{WM}$. The result of the experiment showed that the whole genotypes $\mathrm{A}=\mathrm{SW}-907, \mathrm{~B}=\mathrm{SW}-804, \mathrm{C}=\mathrm{SW}-902, \mathrm{D}=\mathrm{US}-915$, $\mathrm{E}=\mathrm{SW}-82, \mathrm{~F}=\mathrm{SW}-923, \mathrm{G}=\mathrm{WM} 4 \mathrm{SHS}, \mathrm{H}=\mathrm{SL} 8 \mathrm{SHS}$, and $\mathrm{I}=$ Intani 2 measured the height of the plants, the number of productive tillers, the length of the panicles, the number of grains per panicle, the number of filled grains per panicle, the weight of 1000 grains, and the grain yield per plot, and were unstable and unadaptive in Bandung and Tasikmalaya.
\end{abstract}

\section{Contribution/ Originality}

This study significantly contributes to provide recommendations about rice varieties that are adaptive/ suitable for certain regions, such as Indonesia. Information about the stability of genotype and genetic interaction $\mathrm{x}$ environment is very important to know in determining the right variety or strain planted in an environment. It is expected to be able to obtain lines of hope that adapt well in certain environments and are stable in some environments.

DOI: 10.18488/journal.1005/2019.9.2/1005.2.204.215

ISSN (P): 2304-1455/ISSN (E):2224-4433

How to cite: Lia Amalia, Ai Komariah and Ilma Hilmayanti (2019). Stability and adaptability genotype of hybrid rice in the West Java province of Indonesia. Asian Journal of Agriculture and Rural Development, 9(2), 204-215.

(C) 2019 Asian Economic and Social Society. All rights reserved. 


\section{INTRODUCTION}

According to Central Bureau of Statistics (2017), 1.2 million tons of rice imported from Indonesia were recorded from January to November 2016. It is an increase of $110.66 \%$ compared to the same period last year.

Rice production is strategic, because it can strengthen national food security. Efforts to achieve this food security on one hand will help the government to reduce rice imports and on the other hand increase farmers' income (Acuña et al., 2008; Bose et al., 2012; Wireko-Manu \& Amamoo, 2017). Ratna and Ishaq (2011) evaluated the performance and yield of some varieties of rice in the district of Karawang. The results showed a very real difference among the varieties for all characters except the leaf color index. The result parameters were: Ciherang has the highest plants $(97.59 \mathrm{~cm})$, Inpari-7 has a number of productive tillers and the heaviest weight of 100 grains 25 tillers/clump and tonnes ha-1 2.8 grams), and the number of empty grains - 23 grains/panicle). St. Bagendit has the highest number of pithy grain reaching 183 grains/panicle. The Silugonggo variety has the shortest harvest age, but is not resistant to stems brown plant hopper (almost had a crop failure). St. Bagendit has the highest dry grain harvest $\left(8.10\right.$ tonnes $\left.\mathrm{ha}^{-1}\right)$ followed by Ciherang (8.08 tonnes $\left.\mathrm{ha}^{-1}\right)$, Inpari-13 (8.07 tonnes ha $\left.{ }^{-1}\right)$, Inpari-7 (7.52 tonnes ha $\left.{ }^{-1}\right)$, Inpari 10 (6.71 tonnes ha-1), and Silugonggo (2.05 tonnes ha-1).

Various pieces of rice cultivation technology continue to be developed to achieve these efforts. One such effort is the provision of hybrid varieties of high yield, tolerant to extreme environments, stable, and adaptive to the environments in which they are cultivated.

Hybrid rice with a yield potential of $10 \%-25 \%$ higher than not hybrid varieties is an alternative to supporting government programs for rice self-sufficiency. According to Yuniati (2011) there are 44 hybrids yielding higher heterosis than that of the checked variety (Ciherang).

The new varieties improved through a series of crosses require genotypes that have wide genetic variability. Hybrid rice is the result of crossbreeding two mains that show heterosis, especially potential yield. Plant breeding programs heavily rely on genetic variability as a source of elders. Without the required genetic variability the efficiency and effectiveness of plant breeding programs will be very low. Genetic variability can be obtained from local varieties, national superior varieties, introductory lines, experimental lines, and wild relatives of plants. Introduced strains are not always expressed, nor produce higher yields in all environmental conditions. According to Trias et al. (2011) varieties in medium elevation have a higher yield than varieties in low elevation. 4 mutant varieties have been observed to have good plant type, early maturing, and high yielding.

Hybrid rice produced and released in Vietnam, China, India is widely introduced to Indonesia: SW-907, SW-804, SW-902, US-915, SW-82, SW-923, SL 8 SHS, WM 04 SHS. The hybrid rice is adaptive in the country of origin with high yield potential, but it is not yet known whether it will be stable and adaptive and have the potential of a high yield in Indonesia, therefore it is necessary to test it in various environments. The magnitude of the interaction between genotype and environment can be used to measure the stability and adaptability of a genotype that reflects the ability of plants to survive and multiply in various environments (Nor and Cady, 1979 cited in Djaelani et al., 2001). Good soil management is required if the environment is to be a medium for plants to produce good crops (Subandi et al., 2019).

Several hybrids of rice are being developed in West Java, including the Tasikmalaya and Bandung regions. The regions have different biogeophysical conditions, therefore it is good to test the hybrids at these two locations. 
Based on the background the problems to be studied in this research are:

- are there any stable hybrid rice genotypes in Tasikmalaya and Bandung?

- is there a hybrid of rice genotype which is adaptive only in Tasikmalaya or Bandung? (location specific)

This study aims to study the stability and adaptability of several hybrid rice genotypes in Tasikmalaya and Bandung.

The results of the research are expected to enrich the scientific repertoire in agriculture, especially agro technology related to information about the stability and adaptability of hybrid rice genotypes. This information is very important as a reference for determining the direction of breeding programs and as a useful source of information for related agencies in an effort to increase rice production through utilization of hybrid rice genotypes. Evaluation of grain yield in many environments is one of numerous approaches to verifying the stability of genotypes (Acuña et al., 2008). However, the interaction of genotypes with the environment always contributes to the stability of rice varieties (Bose et al., 2012).

Prior experiments indicated an interaction between the genotype and the environment $(\mathrm{G} \times \mathrm{E})$. Studies, among others carried out by Finlay and Wilkinson (1963), and Baihaki and Wicaksana (2008) indicate interaction of the genotypes with the environment.

Baihaki and Wicaksana (2008) found that the interaction of genotypes with environmental information is very important for countries with as wide biogeophysic variability as has Indonesia. Growers may utilize specific environmental contexts in the policy of determining the application of regional policy of distribution of a new superior variety. In this case there are two alternatives: 1. releasing new varieties with high yield potential for wide spatial range (wide adaptability), 2. releasing new varieties with high yield potential at specific regions. High adaptability is synonymous with stability and specific adaptability is identical to adaptivity. Varietal adaptability to environmental fluctuations is important for stabilization of crop production in both regions and seasons. Information on the genotype $\mathrm{x}$ environment interaction is essential to the successful evaluation of stable genotypes (Uma Devi et al., 2008 cited in Pala et al., 2014). Multienvironmental trials (MET) were conducted to evaluate the yield stability performance of different genetic materials under different environmental conditions (Yan et al., 2000; Yan and Tinker, 2006).

The benefits to be gained are whether a region-specific superior variety can be released, including: 1. efficient use of funds and time, 2. multiplying new improved varieties, 3. national productivity to increase, 4. Suppressing the price of the seed, 5. "regional buffering" which is indispensable to reducing the spread of plant pests or diseases, 6. providing an alternative choice of varieties sufficient for farmers, 7. exploiting the potential of natural wealth well, and 8. encouraging sustainable agricultural development (Baihaki and Wicaksana, 2008).

The analysis of adaptability in Baihaki and Wicaksana's research data and stability analysis for spatial environmental indexes during the 2003 planting season showed that six of the tested genotypes were not widely adopted in the eight test sites. However, genotype 3 tended to approach broad adaptation with the coefficient of regression value close to one and the standard deviation coefficient of regression close to zero. The yield per hectare of these six genotypes is quite high, ranging from 2.54 t.ha $^{-1}$ to 3.99 t.ha $^{-1}$ (Baihaki and Wicaksana, 2008).

Based on the definition of stability and adaptability of a genotype used in this study (Baihaki and Wicaksana, 2008), the results of a study conducted by Harsanti and Hambali (2003) at 20 rice strains in 20 environments (sites), there were only two lines showing extensive adaptability, i.e. S3388-Id-PN16-2 strains $(b=1.03$ b S $=0.27)$ and IR lines $64(b=1.01, \mathrm{~b} \mathrm{~S}=0.08)$. The research 
was conducted in a very wide range of locations, ranging from North Sumatra, West Sumatra, Jambi, South Sumatra, Banten, West Java, Central Java, Yogyakarta, Bali, NTT, NTB, South Kalimantan, and South Sulawesi. The average yield of these 10 strains ranged from 5.86 t.ha $^{-1}$ to 6.62 t.ha $^{-1}$. The low number of widely adapted varieties and neglected narrow-adapted varieties, as well as the low number of newly released superior varieties, can illustrate the low efficiency and effectiveness of the superior varieties release process in the country. This will be overcome if the region-specific superior varieties are also taken into account in the release policy of varieties, thus reducing the cost and time that have been wasted.

Genotype interaction with the environment in plants is a real phenomenon. The wide adaptation variety (superior adaptability) is superior and released in number slightly compared with the number of genotypes tested. In addition to broad adaptation varieties, region-specific superior varieties are recommended to be released to improve the efficiency and effectiveness of new improved varieties release process, establish regional buffering, and increase the number of superior varieties of crops so farmers will get alternative options and lower seed prices.

A common way to recognize an ideal strain is to test a set of expected lines in some environmental conditions. Based on the results of variance analysis will be known whether or not the interaction between genotype and the environment. If there is no interaction between the genotype and the ideal lineage environment it will be very easy to do, i.e. by choosing a strain with the highest average yield. However, if an interaction between the genotype and the environment will make it difficult in the selection of an ideal strain that can adapt and stable in all environments because the highest yield on a strain is not necessarily the highest result in different environments. The interaction between genotype and environment is crucial in determining the stability and adaptability of a strain.

If varieties that are adaptive to a particular environment are desired, strains that interact very clearly with the environment must be obtained. Conversely, if desired cultivars that are stable or widely adopted then should be obtained strains that do not or less interaction with the environment (Satoto, 1996).

The results of Satoto (1996), stable hybrid rice based on stability analysis were hybrid IR54752 A x IR46R, IR54752a x IR 21916 and IR54752A x IR19392 because they had higher yield averages than IR 64 with $b_{i}$ values approaching 1 (one). Such hybrids are responsive to environmental variations similar to the average of genotypes tested, meaning they have a fairly stable stability. Hybrid IR54752A x IR19058-107-1, IR54752A x Krueng Aceh, and IR54752A x Sadang have $b_{i}$ values greater than 1 (one) so that the three hybrids have responses to environmental variations above the average genotype tested. The three hybrids are hybrids that are location specific or can be classified on unstable hybrids. This means that in an environment that is less suitable hybrids it will give low results but once get good environmental support it will give high results.

Based on the above-mentioned thinking, the hypothesis can be determined as follows:

1. There are several stable hybrid rice genotypes in Bandung and Tasikmalaya regencies.

2. There are several hybrid rice genotypes that are adaptive in Bandung regency and in Tasikmalaya district.

\section{MATERIALS AND METHODS}

The experiments were conducted by using the experimental approach in two different locations, namely Arjasari Village, Leuwisari Sub-district, Tasikmalaya Regency with altitude $450 \mathrm{~m}$ above sea level and in Jelekong Village, Baleendah Sub-District, Bandung with altitude $650 \mathrm{~m}$ above sea level. 
The materials used in the experiment included hybrid rice seeds of 9 genotypes, namely; Genotype SW-907, SW-804, SW-902, US-915, SW-82, SW-923, Intani-2, SL 8 SHS, WM 04 SHS, Urea fertilizer (45\% N), SP 36 (36\% P2O5), KCl (56\% K2O), Furadan 3 G, Matador 50 EC, Dithane M $4580 \mathrm{WP}$ and Agrep $25 \mathrm{WP}$.

The tools used include hand tractor, hoe, hand sprayer, cored, bucket, with measuring instrument such as $5 \mathrm{~kg}$ weight scales and measuring cup, meter, wet ball-ball thermometer, and treatment plank, and stationery. The experimental approach using Randomized Block Design (RBD) is a simple one-factor pattern, i.e. several hybrid rice genotypes replicated three times. Each replication consisted of 9 treatment of hybrid rice genotypes placed randomly on experimental patches measuring $5.0 \mathrm{~m} \times 3.0 \mathrm{~m}=\left(15 \mathrm{~m}^{2}\right)$.

Variables in the study consist of the independent variable (Independent Variable) and dependent variable. The independent variable, i.e. the treatment of several hybrid rice genotypes consisting of nine levels with the operationalization of variable types is presented in Table 1.

The dependent variable is in the form of hybrid rice genotypes the response The response variable is used to answer the hypothesis so that the data are analyzed using statistical analysis.

The main response modifiers for yield power characteristics were performed on 5 (five) sample plants in the form of clumps present in the plot of $5.0 \mathrm{~m}$ x $3.0 \mathrm{~m}$. To obtain yield per plot and yield conversion per hectare observation of all crops in the experimental plot.

\section{Table 1: Operationalization of variables}

\begin{tabular}{|c|c|c|}
\hline Variable Type & Sub Variable & Indicator Variable \\
\hline Dependent Variable & Hybrid Rice Genotypes & $\begin{array}{l}\mathrm{A}=\text { Genotype SW-907 } \\
\mathrm{B}=\text { Genotype SW-804 } \\
\mathrm{C}=\text { Genotype SW-902 } \\
\mathrm{D}=\text { US-915 Genotype } \\
\mathrm{E}=\text { Genotype SW-82 } \\
\mathrm{F}=\text { Genotype SW-923 } \\
\mathrm{G}=\text { WM } 4 \text { SHS genotype } \\
\mathrm{H}=\text { Genotype SL } 8 \text { SHS } \\
\mathrm{I}=\text { Intani-2 Genotype }\end{array}$ \\
\hline Independent Variable & Yield Component & $\begin{array}{l}\text { 1. Plant height } \\
\text { 2. Long panicle } \\
\text { 3. Number of productive tillers per hill } \\
\text { 4. Number of grains per panicle } \\
\text { 5. The number of grain content per panicle } \\
\text { 6. Weight of } 1000 \text { grains }\end{array}$ \\
\hline & Yield of Plant & Results of Crop Unhulled harvest \\
\hline
\end{tabular}

Primary data were obtained by measuring simple sample random sampling. The sample size is 5 plants in each plot and the number of plants per plot is 240 clumps of plants.

The research hypothesis is as follows:

$\mathrm{H}_{0}: \mathrm{u}_{1}=\mathrm{u}_{2}=\mathrm{u}_{3}=\ldots \ldots \mathrm{U}_{\mathrm{n}}$

$\mathrm{H}_{1}: \mathrm{u}_{1} \neq \mathrm{u}_{2} \neq \mathrm{u}_{3} \neq \ldots \ldots \mathrm{U}_{\mathrm{n}}$

Or at least a pair of different treatments.

The observed data were analyzed by combined analysis. Stability was calculated using analysis models with the following linear equations (Gomez and Gomez, 1995). 
$(I=1,2,3, \ldots . ., t$ and $j=1,2,3, \ldots . ., s)$

$$
Y_{i j}=m_{i}+b_{i l j}+d_{i j}
$$

Where:

$\mathrm{Y}_{\mathrm{ij}}=$ average $i$ curve in $j$ environment

$\mathrm{m}_{\mathrm{i}}=$ average $i$ strain in all environments

$\mathrm{B}_{\mathrm{i}}=$ regression coefficient of the $i$ strain of the environmental index

$\mathrm{I}_{\mathrm{j}}=$ environmental index, i.e. the mean deviation of all strains in an environment from the average

$\mathrm{D}_{\mathrm{ij}}=$ regression deviation for $i$ line in $j$ environment

The parameters used to measure the stability are the regression coefficients $\left(b_{i}\right)$ and the standard deviation $\left(\mathrm{SD}_{\mathrm{i}}\right)$. The regression coefficient is the appearance of each strain in different environments against the average environment for all genotypes. A strain is said to be stable if it has one regression coefficient $(b=1)$ and the deviation is not significantly different from zero.

\section{RESULTS AND DISCUSSION}

The general condition of cultivation between the research sites of Bandung and Tasikmalaya has differences. The Jelekong village district of the Baleendah Bandung region is 650 meters above sea level and has a type C (slightly wet) rainfall, while the Arjasari Village LeuwisariTasikmalaya district sits at 450 meters above sea level with type D (medium) precipitation.

Pest and diseases may lower the crops (Subandi et al., 2017; Frasetya et al., 2019). Pests and diseases attacking rice cultivation in these two locations do not disrupt the experiment. Generally pests that attack the experimental crops are aphis plant hoppers. Pests can be controlled by application of insecticides score at a $2.00 \mathrm{ml}$ concentrations of $\mathrm{L}^{-1}$ solution and the disease that attacks the trial rice plants is BLB. The disease can be controlled by pesticides Dithane M 4580

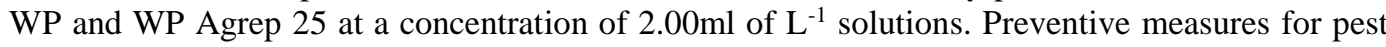
control nematode species used Furadan $3 \mathrm{G}$ by means of sowing the crop land.

Weeds that grew in the rice during the trial were from a species of the jajagoan (Echonochloa vulgari) grass, broad-leaved babadotan (Ageratum conyzoides), and wild amaranth (Amaranthus spinosus). Weed was controlled by tossing the soil with a hoe. Damage to crops due to weed infestation or pest attack was within tolerable limits, so the trial could continue.

The authors of this study also conducted observations of 50\% age interest and harvest age as shown in the following table:

Table 2: Age data 50\% flowering and harvest age rice genotype in Bandung and Tasikmalaya

\begin{tabular}{|c|c|c|c|c|}
\hline \multirow[t]{2}{*}{ Genotype } & \multicolumn{2}{|c|}{$\begin{array}{c}\text { Age Genotype 50\% Flowering } \\
\text { (Day after Planting) }\end{array}$} & \multicolumn{2}{|c|}{$\begin{array}{c}\text { Harvest Age } \\
\text { (Day After Planting) }\end{array}$} \\
\hline & Bandung & Tasikmalaya & Bandung & Tasikmalaya \\
\hline$A=S W-907$ & 78 & 79 & 122 & 121 \\
\hline $\mathrm{B}=\mathrm{SW}-804$ & 68 & 68 & 113 & 113 \\
\hline $\mathrm{C}=\mathrm{SW}-902$ & 68 & 68 & 113 & 115 \\
\hline $\mathrm{D}=\mathrm{US}-915$ & 85 & 85 & 134 & 139 \\
\hline$E=S W-82$ & 78 & 75 & 122 & 122 \\
\hline $\mathrm{F}=\mathrm{SW}-923$ & 78 & 80 & 129 & 130 \\
\hline $\mathrm{G}=\mathrm{WM} 4 \mathrm{SHS} 1$ & 78 & 78 & 125 & 125 \\
\hline $\mathrm{H}=\mathrm{SL} 8 \mathrm{SHS}$ & 78 & 85 & 127 & 129 \\
\hline $\mathrm{I}=\mathrm{Intani}-2$ & 78 & 78 & 125 & 125 \\
\hline
\end{tabular}


The table shows that the harvest ages of 9 rice genotypes grows each day. It is suspected that environmental factors have an effect on the genotype of the rice. Environmental factors that are highly influential on the age of the harvest and flowering are the condition of water. During the experiment rain fall for 7 days causing the water condition in the crops to be available and flooded. This condition encourages vegetation to become stronger for longer.

Superior rice varieties generally mature in 105-125 days, whereas local rice varieties mature in 150-180 days. The observed age of 50\% flowering and the harvest age (physiological ripening) of the 9 genotypes tested as listed in Table 3 showed the shortest or most moderate SW-804 and SW902 genotypes of 113 days and the longest US-915 genotype of 134 days.

The observed age of 50\% flowering and harvest age of 9 genotypes tested as listed in Table 4 showed the shortest or most moderate SW-804 genotype of 113 days and the longest US-915 genotype of 139 days.

In addition to the above the supporting observations in this experiment include qualitative characters consisting of 13 indicators of variables using standards from UPOV (Union internationale pour la Protection des Obstention Vegetalis) or International Union of Plant Variety Protection, including crop shape, stem color, stem strength, leaf ear color, leaf tongue color, leaf color, leaf face, leaf position, flag leaf, grain shape, grain color, and hair loss. The results of observations of the leaf character indicated in Table 5 can be recommended for temporary description of the unreleased genotypes. Morphological observations of genotype G (WM 4 SHS), H (SL-8 SHS), and I (Intani 2) are similar to those listed in the description and these are varieties that have been released by the National Seed Agency.

The results of qualitative observation of several tested rice genotypes showed variation in plant shape, leaf blade, grain shape, grain color, and grain loss. The SW-923 genotype has a standing grove of trees that form an angle of $>30^{\circ}$ and $<45^{\circ}$, so the morphology of the plant form is exposed. Other genotypes have a rectangular angle of less than $30^{\circ}$. The angle of the leaf blade on the SW-923 genotype is $45^{\circ}$ and the other genotype is less than $30^{\circ}$. Genotype US-915 has a moderate grain (the ratio of grain length to width is between 2.1-3 and 0), while the other genotype has a slender grain (higher than 3.0). The color of the grain of the SW-82 genotype is clear yellow, while that of the other genotype is yellow straw. The level of hair loss varies from difficult through moderate to easy, based on the easy size of grain falling out when the panicle is grasped by hand. The loss criterion is calculated from the percentage of unhulled grain as difficult if the level of loss is $<25 \%$; moderate if $25 \%-50 \%$; and easy if $>50 \%$.

Table 3: Qualitative character of hybrid rice genotypes in Bandung and Tasikmalaya

\begin{tabular}{lccccccccc}
\hline $\begin{array}{l}\text { Qualitative } \\
\text { Character }\end{array}$ & $\mathbf{9 0 7})$ & $\mathbf{8 0 4})$ & $\mathbf{9 0 2})$ & $\mathbf{9 1 5})$ & $\mathbf{8 2})$ & $\mathbf{9 2 3})$ & $\begin{array}{c}\text { (WM4 } \\
\text { SHS }\end{array}$ & $\begin{array}{c}\text { H (SL8 } \\
\text { SHS }\end{array}$ & $\begin{array}{c}\text { I (Intani } \\
\text { 2) }\end{array}$ \\
\hline $\begin{array}{l}\text { Crop shape } \\
\text { Foot color }\end{array}$ & Upright & Upright & Upright & Upright & Upright & Upright & Upright & Upright & Upright \\
$\begin{array}{l}\text { Stem color } \\
\text { Leaf ear } \\
\text { color }\end{array}$ & Green & Green & Green & Green & Green & Green & Green & Green & Green \\
$\begin{array}{l}\text { Leaf tongue } \\
\text { color }\end{array}$ & Colorless Colorless Colorless & Colorless Colorless Colorless & Colorless Colorless Colorless & Green & Green & Green & Green & Green \\
$\begin{array}{l}\text { The color } \\
\text { of the leaf }\end{array}$ & Green & Green & Green & Green & Green & Green & Green & Green & Green \\
$\begin{array}{l}\text { Surface of } \\
\text { the leaf }\end{array}$ & Rugged & Rugged & Rugged & Rugged & Rugged & Rugged & Rugged & Rugged & $\begin{array}{c}\text { Rather } \\
\text { Rugged }\end{array}$ \\
Leaf & Upright & Upright & Upright & Upright & Upright & Upright & Upright & Upright & Upright \\
\hline
\end{tabular}




\begin{tabular}{lccccccccc}
\hline position & & & & & & & & \\
Leaf blade & Upright & Upright & Upright & Upright & Upright & Upright & Upright & Upright & Upright \\
Shape of & Slim & Slim & Slim & Medium & Slim & Slim & Slim & Medium & Medium \\
Grain & Yellow & Yellow & Yellow & Yellow & Yellow & Yellow & Yellow & Yellow & Yellow \\
Color grain & $\begin{array}{c}\text { straw } \\
\text { straw }\end{array}$ & straw & straw & straw & straw & straw & straw & straw \\
Loss grain & Medium & $\begin{array}{c}\text { Easy to } \\
\text { loss }\end{array}$ & Difficult & Medium & Medium & Medium & Medium & Medium Medium \\
\hline
\end{tabular}

Thus the characteristics of plant shape, leaf blade, grain shape, grain color, and grain loss can be used as markers or morphological markers for rice plants.

In general the appearance of all qualitative characters observed in Bandung and in Tasikmalaya are not very different. This indicates that this qualitative character is more controlled by genetic factors than the environment, meaning that the environment has very little effect on the characters. Thus the characters are stable and do not change appearance in Bandung nor Tasikmalaya.

The main observation data which were tested statistically include: plant height, number of productive tillers per hill, the length of the panicles, the number of grains per panicle, the weight of 1000 grains, and the yield of dry grain harvest per plot.

Based on the analysis of Finlay-Wilkinson stability the average value and parameter value of stability correlation are coefficient $\left(\mathrm{b}_{\mathrm{i}}\right)$ and regression deviation $\left(\mathrm{SD}_{\mathrm{i}}\right)$ for plant height, the number of productive tillers per hill, the number of grains per panicle, the number of grains of fill per panicle, the weight of 1000 grains, and the yield of dry grain harvest per plot in Table 3 . The table shows that all characters observed in all genotypes tested unstable both in Bandung and Tasikmalaya, which was not in accordance with the initial hypothesis. The instability of character is indicated by the $b_{i}<1$ or $b_{i}>1$. The stable character has $b_{i}=1$. According to Finlay and Wilkinson (1963) $b_{\mathrm{i}}<1$ indicates that the plant has above average stability and is a specially adapted genotype in marginal environments, meaning that with environmental changes the genotype gives only slight changes to the results and $b_{i}>1$ values, which means that the characters are unstable and the genotype is adaptable in the optimal environment.

The instability of all the observed characters including the resultant character is suspected because the characters are influenced by the genotype interaction with the environment because the controller of the quantitative control character consists of many genes or multigenic characters. That means that many genes play a role in controlling the nature of the outcome and each gene is small and cumulative. According to Jalaludin et al. (1993) cited in Nursanti et al. (2014) control gene results always lie in different chromosomes, so breeding programs to obtain high and stable results are very difficult to implement. However, although it is very difficult to implement the stability of the results, it is possible to get because according to Ratna and Ishaq (2011) factors causing the stability of the genotype results are not clearly known. It is suspected that the mechanisms of individual and population buffer are the contributing factors. Stability mechanisms in general can be grouped into four things: genetic heterogeneity, component compensation, stress tolerance, and rapid recovery of resources. And Subandi and Dikayani (2018) said that growth form is an important regulation of plant development. 
Table 4: Plant harvest characteristics per plot of 9 rice hybrid genotypes

\begin{tabular}{|c|c|c|c|c|c|c|c|c|c|c|c|c|c|c|c|c|c|c|c|c|c|}
\hline \multirow[t]{2}{*}{ Genotypes } & \multicolumn{3}{|c|}{ Plant Height } & \multicolumn{3}{|c|}{$\begin{array}{c}\text { Number of Puppies } \\
\text { Productive }\end{array}$} & \multicolumn{3}{|c|}{ Length of Panicle } & \multicolumn{3}{|c|}{$\begin{array}{l}\text { Number of Grain } \\
\text { per Panicle }\end{array}$} & \multicolumn{3}{|c|}{$\begin{array}{c}\text { Number of Fill } \\
\text { Grain per Panicle }\end{array}$} & \multicolumn{3}{|c|}{$\begin{array}{c}\text { Weight } 1000 \\
\text { Grains }\end{array}$} & \multicolumn{3}{|c|}{ Dry Grain yield } \\
\hline & $\begin{array}{c}\text { Rata- } \\
\text { rata }\end{array}$ & $\left(\mathbf{b}_{\mathbf{i}}\right)$ & $\left(\mathbf{S D}_{\mathbf{i}}\right)$ & $\begin{array}{c}\text { Rata- } \\
\text { rata }\end{array}$ & $\left(\mathbf{b}_{\mathbf{i}}\right)$ & $\left(\mathbf{S D}_{\mathbf{i}}\right)$ & $\begin{array}{c}\text { Rata- } \\
\text { rata }\end{array}$ & $\left(\mathbf{b}_{\mathbf{i}}\right)$ & $\left(\mathbf{S D}_{\mathbf{i}}\right)$ & $\begin{array}{l}\text { Rata- } \\
\text { rata }\end{array}$ & $\left(\mathbf{b}_{\mathbf{i}}\right)$ & $\left(\mathrm{SD}_{\mathbf{i}}\right)$ & $\begin{array}{c}\text { Rata- } \\
\text { rata }\end{array}$ & $\left(b_{i}\right)$ & $\left(\mathrm{SD}_{\mathbf{i}}\right)$ & $\begin{array}{c}\text { Rata- } \\
\text { rata }\end{array}$ & $\left(\mathbf{b}_{\mathbf{i}}\right)$ & $\left(\mathrm{SD}_{\mathbf{i}}\right)$ & $\begin{array}{l}\text { Rata- } \\
\text { rata }\end{array}$ & $\left(b_{i}\right)$ & $\left(\mathbf{S D}_{\mathrm{i}}\right)$ \\
\hline $\begin{array}{l}A=S W- \\
907\end{array}$ & 110.97 & 0.89 & 0.00 & 21.42 & 0.24 & 0.00 & 23.97 & -2.29 & 0.00 & 191.12 & -0.67 & 0.00 & 145.30 & 0.39 & 0.00 & 22.31 & -0.04 & 0.00 & 13.97 & 0.48 & 0.00 \\
\hline $\begin{array}{l}B=S W- \\
804\end{array}$ & 108.20 & 1.48 & 0.00 & 20.62 & 0.89 & 0.00 & 23.01 & 8.88 & 0.00 & 205.95 & -0.63 & 0.00 & 156.96 & 0.32 & 0.00 & 22.31 & 1.28 & 0.00 & 14.68 & 0.93 & 0.00 \\
\hline $\begin{array}{l}\mathrm{C}=\mathrm{SW}- \\
902\end{array}$ & 106.70 & 1.81 & 0.00 & 19.93 & 0.25 & 0.00 & 22.90 & 13.26 & 0.00 & 207.76 & -0.37 & 0.00 & 157.80 & 0.32 & 0.00 & 23.62 & -0.37 & 0.00 & 14.10 & 0.96 & 0.00 \\
\hline $\begin{array}{l}\mathrm{D}=\mathrm{US}- \\
915\end{array}$ & 113.28 & 0.37 & 0.00 & 22.70 & 2.06 & 0.00 & 23.18 & 2.14 & 0.00 & 196.84 & 9.82 & 0.00 & 154.97 & 5.00 & 0.00 & 22.75 & -3.05 & 0.00 & 17.02 & 1.74 & 0.00 \\
\hline $\begin{array}{l}\mathrm{E}=\mathrm{SW}- \\
82\end{array}$ & 117.58 & 1.62 & 0.00 & 21.80 & 1.49 & 0.00 & 25.03 & 1.56 & 0.00 & 206.97 & 2.51 & 0.00 & 159.55 & 1.78 & 0.00 & 20.14 & 1.03 & 0.00 & 16.12 & 1.21 & 0.00 \\
\hline $\begin{array}{l}F=S W- \\
923\end{array}$ & 115.33 & 0.97 & 0.00 & 20.85 & 0.53 & 0.00 & 25.10 & 0.07 & 0.00 & 207.88 & -0.61 & 0.00 & 158.41 & 0.32 & 0.00 & 25.31 & 0.91 & 0.00 & 16.55 & 1.12 & 0.00 \\
\hline $\begin{array}{l}\mathrm{G}=\mathrm{WM} 4 \\
\mathrm{SHS}\end{array}$ & 104.85 & 1.12 & 0.00 & 21.45 & 1.15 & 0.00 & 18.60 & -5.42 & 0.00 & 187.98 & 1.47 & 0.00 & 143.52 & 1.14 & 0.00 & 24.98 & 0.21 & 0.00 & 14.52 & 1.11 & 0.00 \\
\hline $\begin{array}{l}\mathrm{H}=\mathrm{SL} 8 \\
\text { SHS }\end{array}$ & 100.50 & 0.90 & 0.00 & 22.22 & 1.05 & 0.00 & 19.86 & 112.36 & 0.00 & 179.15 & -2.52 & 0.00 & 135.16 & -0.60 & 0.00 & 26.48 & 2.23 & 0.00 & 13.88 & 0.57 & 0.00 \\
\hline $\begin{array}{l}I=\text { Intani- } \\
2\end{array}$ & 100.80 & -0.17 & 0.00 & 21.50 & 1.34 & 0.00 & 23.48 & 3.16 & 0.00 & 193.86 & 0.00 & 0.00 & 146.41 & 0.32 & 0.00 & 27.73 & 6.81 & 0.00 & 12.65 & 0.89 & 0.00 \\
\hline
\end{tabular}


In this context stability is defined as a genotype that has genetic heterogeneity to avoid large yield changes in different environments. This mechanism arises from the result of the collaboration of various (heterogeneous) genes contained in the genetic makeup of a strain. This is understandable since the results are product of the various components of the outcome and the component of the outcome itself is a product of the genes. With the variety of products produced by a strain due to the heterogeneity of the strain reduction of the yield from one component will be replaced by the other components and result in stability. Nine studied genotypes were hybrid strains in which the individual population was uniform or homogenous, making it very difficult to stabilize, especially in yields in various environments.

Adaptability of a character in view of the real or not real interaction between the genotype and the environment: if the genotype interaction with the real environment is real, the character is adaptive. If the interaction between the genotype and its environment is not real, the character is not adaptive. Based on the Finlay-Wilkinson combined analysis calculation the result of $\mathrm{F}$ arithmetic and $\mathrm{F}$ interaction tables of high plant character genotypes, the number of productive tillers, the length of the panicles, the number of grains per panicle, the weight of 1000 grains, and dry grain yield is displayed in the following table:

Table 5: Value of $F$ count and $F$ table of genotype interaction with the environment: 9 hybrid genotypes in Bandung and Tasikmalaya

\begin{tabular}{lcc}
\hline Character & $\mathbf{F}_{\text {count }}$ & $\mathbf{F}_{\mathbf{t} 0.5}$ \\
\hline Plant height & 0.22 & 2.23 \\
Number of Productive Tillers & $7.60^{* *}$ & 2.24 \\
Length of Panicle & $3.57 * *$ & 2.24 \\
Number of Grain per Panicle & 1.61 & 2.24 \\
Total Grain of Content per Panicle & 0.22 & 2.23 \\
Weight of 1000 grains & 0.22 & 2.23 \\
Weight of Dry Harvest & 0.22 & 2.23 \\
\hline
\end{tabular}

** shows significant

The interaction between genotype and its environment is not significantly different for the weight of dry harvest. It means that all tested genotypes are not adaptive in Bandung nor Tasikmalaya. This is reinforced by the value of the interaction of plant height characters, the number of grains per panicle, and the weight of 1,000 grains that is not real either, although there are two characters that have the value of interaction between the genotype and the real environment - the number of productive tillers and long panicle. The number of productive tillers and the length of a panicle bears no significant correlation to the results. This means that if the number of productive tillers is high but the panicle is not long and the number of grains is low, the-yield is not optimal.

Generally the characteristic weight of dry harvest is strongly influenced by the environment, hence the environmental effect is very real to the results. However, in this research the value of interaction between genotype and intangible environment is supported by the character interaction value that has correlation to the result that is the character of plant height to the number of grains per panicle. The number of grains per panicle and the weight of 1,000 grains that is not real. This condition illustrates that the diversity of plant height, number of grains per panicle, and weight of 1,000 grains among the tested strains is due to genetic differences in the strains and the environment in which they grow, while the effect is very small in interaction of strains with the environment.

This is allegedly because the environment in both testing sites to nine hybrid rice genotypes, namely the Bandung and Tasikmalaya regions, are relatively the same. The type of rainfall in Bandung is $C$ (slightly wet) with rainfall during research ranging from $54 \mathrm{~mm}$ to $317 \mathrm{~mm}$ and the 
height of 650mdpl. The type of rainfall in the Tasikmalaya district is D (medium) with rainfall during research ranging from $80 \mathrm{~mm}$ to $577 \mathrm{~mm}$ and the height of $450 \mathrm{mdpl}$. The need for hybrid rice in the tropics during the dry season ranges from $427 \mathrm{~mm}$ to $511 \mathrm{~mm}$ (Setiobudi, 2008). Rainfall during research in Bandung does not meet the range of need for hybrid rice in general, but the water needs can be fulfilled through technical cultivation and irrigation techniques. Sitaresmi et al. (2011); Sitaresmi et al. (2016); and Yuniati (2011) maintain that if the interaction of genotype with the environment is weak, then the relative appearance ratings of a genotype from one location to another will be relatively the same.

\section{CONCLUSION}

Based on the results of research and discussion it can be concluded that: There is no stable hybrid rice genotype in Kab, Tasikmalaya, and Bandung except for the character of the number of productive tillers and long panicles. And there is no adaptive hybrid paddy genotype in sub districts of Tasikmalaya and in Bandung.

\section{Funding: This study received no specific financial support.}

Competing Interests: The authors declared that they have no conflict of interests.

Contributors/Acknowledgement: All authors participated equally in designing and estimation of current research.

Views and opinions expressed in this study are the views and opinions of the authors, Asian Journal of Agriculture and Rural Development shall not be responsible or answerable for any loss, damage or liability etc. caused in relation to/arising out of the use of the content.

\section{References}

Acuña, T. L. B., Lafitte, H. R., \& Wade, L. J. (2008). Genotype environment interactions for grain yield of upland rice backcross lines in diverse hydrological environments. Field Crops Research, 108(2), 117-125.

Baihaki, A., \& Wicaksana, N. (2008). Genotype Interaction x Environmental, adaptability, and yield stability in the development of high yielding varieties in Indonesia. Zuriat, 16(1), 18.

Bose, L. K., Nagaraju, M., \& Singh, O. N. (2012). Genotype vs environment interaction and stability analysis of lowland rice genotypes. Journal of Agricultural Sciences, 57(3), 1-8.

Central Bureau of Statistics. (2017). Statistics of Indonesia. Central Bureau of Statistics, Jakarta.

Djaelani, A., Nasrullah, K., \& Soemartono. (2001). Interaction of G x E, adaptability, and stability of soybean strains in multilocation tests. Zuriat, 12(1), 27-33.

Finlay, K. W., \& Wilkinson, G. N. (1963). The analysis of adaptation in a plant breeding program. Aust. J. Agric. Res., 14, 742-752.

Frasetya, B., Harisman, K., Sudrajat, D., \& Subandi, M. (2019). Utilization of rice husk silicate extract to improve the productivity of paddy Ciherang cultivar. Bulgarian Journal of Agricultural Science, 25(3), 499-505.

Gomez, K. A., \& Gomez, A. A. (1995). Statistical procedures for agricultural research. Second Edition. Translation. UI Press.

Harsanti, L., \& Hambali, M. (2003). An adaptation power analysis of 10 wetland rice mutant strains in 20 test sites in two seasons. Zuriate, 14(1), 1-7.

Nursanti, E., Nur, A., Azrai, M., \& Trikoesoemaningtyas (2014). Genetic x environment interaction and genetic variability of introduced wheat lines (Triticum aestivum L.) in tropical agroecosystem. AgroBiogen Journal, 10(3), 93-100.

Pala, A. D., Endino, C. A., Sioco, I. M. G., Ines, L. T., \& Libetario, E. M. (2014). Adaptability and stability analysis of newly-released rice varieties using GGE biplot analysis. Asia Life Sciences, 23(2), 517-527. 
Ratna, R. W., \& Ishaq, I. M. (2011). Evaluation performance and yield of some rice varieties in karawang district proceedings of the national seminar: December 10, 2011. Agriculture Plant Breeding Study Program, University of Padjadajaran: 316-324.

Satoto, S. B. (1996). Stability of ten hybrid rice yields of IR54752A sterile male lineage. Zuriat, 7(1), 27-33.

Setiobudi, D., Abdullah, A., \& Suhartatik, E. (2008). Interaction between varieties and types of soil with $N$ fertilizer and micro elements in increasing yield of new types of rice. In proceedings of the food plants "symposium on plant technology innovation (Book 2). Center for Research and Development of Food Crops. Agricultural Research and Development Agency. Indonesia.

Sitaresmi, T., Gunarsih, C., \& Yamin, S. (2011). Mutant lines of local rice adaptation in different environment elevations. Center for Rice Research. In Proceedings of the National Seminar: December 10, 2011. Agriculture Plant Breeding Study Program, Padjadajaran University, Indonesia.

Sitaresmi, T., Gunarsih, C., Nafisah, N. Y., Abdullah, B., Hanarida, I., Aswidinnoor, H., Muliarta, I. G. P., Daradjat, A. A., \& Suprihatno. (2016). Genotype x Environment interaction of grain yield in rice genotype. Food Agriculture Research Journal, 35(2), 89-97.

Subandi, M., \& Dikayani, E. F. (2018). Production of reserpine of Rauwolfia serpentina (L) kurz ex benth through in vitro culture enriched with plant growth regulators of NAA and kinetin. International Journal of Engineering \& Technology, 7(2.29), 274-278.

Subandi, M., Abdelwahab, M. M., \& Cecep, T. (2019). A review of Egyptian afforestation program and its effect on agriculture. Asian Journal of Agriculture and Rural Development, 9(1), 1-18.

Subandi, M., Setiati, Y., \& Mutmainah, N. H. (2017). Suitability of Corcyra cephalonica eggs parasitized with Trichogramma japonicum as intermediate host against sugarcane borer Chilo auricilius. Bulgarian Journal of Agricultural Science, 23(5), 779-786.

Trias, S., Cucu, G., \& Yamin, S. (2011). Mutant lines of local rice adaptation in different environment elevations. Center for Rice Research. In the Proceedings of the National Seminar: December 10, 2011. Agriculture Plant Breeding Study Program, Padjadajaran University: 513-524.

Uma Devi, K., Padmavathi, J., Uma Maheswara Rao, C., Khan, A. A. P., \& Mohan, M. C. (2008). A study of host specificity in the entomopathogenic fungus Beauveria bassiana (Hypocreales, Clavicipitaceae). Biocontrol Science and Technology, 18(10), 975-989.

Wireko-Manu, F. D., \& Amamoo, C. (2017). Comparative studies on proximate and some mineral composition of selected local rice varieties and imported rice brands in Ghana. Agriculture and Food Sciences Research, 4(1), 1-7.

Yan, W., \& Tinker, N. A. (2006). Biplot analysis of multi-environment trial data: Principles and applications. Canadian Journal of Plant Science, 86(2), 623-645.

Yan, W., Hunt, L. A., Sheng, Q., \& Szlavnics, Z. (2000). Cultivar evaluation and megaenvironment investigation based on the GG E biplot. Crop Science, 40(2), 597-605.

Yuniati, P. M. (2011). Heterosis performance of several hybrid rice varieties at irrigated Lowland. Rice Research Installation. Proceedings of the National Seminar: December 10, 2011. Agriculture Plant Breeding Study Program, University of Padjadajaran, Indonesia. 